\title{
Ex vivo metabolic fingerprinting identifies biomarkers predictive of prostate cancer recurrence following radical prostatectomy
}

Peder R Braadland, Guro Giskeødegård, Elise Sandsmark, Helena Bertilsson, Leslie R Euceda, Ailin F Hansen, Ingrid J Guldvik, Kirsten M Selnæs, Helene H Grytli, Betina Katz, Aud Svindland, Tone F Bathen, Lars M Eri, Ståle Nygård, Viktor Berge, Kristin A Taskén and May-Britt Tessem

Correction to: British Journal of Cancer (2017) 117, 1656-1664. doi:10.1038/bjc.2017.346; published online 3 October 2017

There is an error in final paragraph of the Discussion. The correct sentence is:

In summary, low concentration of spermine and high tChoCre/ Spm ratio, determined by HR-MAS MRS of prostate cancer tissue, were associated with shorter time to recurrence.
The results are correctly described throughout the rest of the manuscript, but in this sentence the words 'low' and 'high' were used incorrectly.

This work is published under the standard license to publish agreement. After 12 months the work will become freely available and the license terms will switch to a Creative Commons AttributionNonCommercial-Share Alike 4.0 Unported License. 